\title{
Legal Protection of Participants Applications for Land Certificates through Complete Systematic Land Registration (PTSL) In Blora Regency
}

\author{
Sriyono $^{1}$ and Amin Purnawan ${ }^{2}$
}

Abstract: The ATR / BPN Ministry launched a Systematic Complete Land Registration (PTSL) as a National Priority Program. This program is intended for middle to low income groups who can have land rights certificates at a low cost, as well as to provide legal certainty guarantees to holders of land rights. One important thing that must be considered in the implementation of PTSL is the availability of laws and regulations that protect the PTSL process and products. The formulation of the problem in this research is what is the form of legal protection for participants in a complete systematic land registration program (PTSL) in Blora Regency. The method used is sociological juridical. The specifications in this study are descriptive analysis. The data used for this study are primary and secondary data obtained from the field observation, interviews, and literature study methods. Based on the research concluded with the Regulation of the Minister of Agrarian Spatial Planning / Head of the National Land Agency Number 6 of 2018 On Complete Systematic Land Registration if there are parties who feel their interests are harmed, they can submit an objection to the official who issues the discretionary decision.

Keywords: Legal Protection; Land Rights Certificate; Complete Systematic Land Registration.

\section{Introduction}

The basic policy of national development is contained in the Preamble of the 1945 Constitution of the Republic of Indonesia, which is to protect the whole nation and all of Indonesia's blood, promote public welfare, educate the nation's life and participate in carrying out world order based on independence, lasting peace and social justice. Of all the development sectors, policies on land legality are a very important part of the community who need legal certainty over their land, both land for settlement and land for business. Communities can be more productive if the land they own has legal certainty.

In accordance with the provisions of Article 33 Paragraph (3) of the 1945 Constitution as the main foundation of national development in the field of land, which states that:

"The earth and water and the wealth contained therein are controlled by the State and are used to the greatest extent possible for the prosperity of the people".

The 1945 Constitution of the Republic of Indonesia has stated that the Indonesian State is a state based on law (rechstaat) and not based on mere power (machstaat). Likewise with regard to land, the government is obliged to provide legal certainty on the status of land controlled by the community or business entity. The Indonesian state has guaranteed the rights of its people. As a democratic state based on the

\footnotetext{
${ }^{1}$ Student of Master of Law, Universitas Islam Sultan Agung Semarang and Civil Servant, email Sriyono1168@gmail.com

${ }^{2}$ Lecturer of Faculty of Law, Sultan Agung Islamic University (UNISSULA), Semarang
} 
Pancasila and the 1945 Constitution of the Republic of Indonesia, and upholds human rights and guarantees all citizens at the same time their positions in law and government are no exception. ${ }^{3}$

Land granted to and owned by people with rights provided by the Basic Agrarian Law (UPPA), is for use or use. The granting and possession of land with these rights will not be meaningful if its use is limited to land as the surface of the earth. For whatever purposes you cannot, you must also use a part of the earth's body underneath it and the water and the space above it. ${ }^{4}$

Problems that are usually debated by people who do not have proof of ownership or land rights certificates. These disputes can cause prolonged conflicts between members of the community which can cause many victims. Then the community needs to register the land in order to obtain a certificate of land rights which serves as a strong proof of ownership of land rights. However, the legal power of certificates of land rights as proof of ownership, the proof can still be paralyzed by other evidence that can prove otherwise so it is not absolute. ${ }^{5}$

The complexity of the problem of land registration is one of the main concerns of the government. To overcome this problem, the government through the ATR / BPN Ministry launched a Systematic Complete Land Registration (PTSL) as a National Priority Program. The program is outlined in the Regulation of the Minister of Agrarian Affairs and Spatial Planning / Head of the National Land Agency of the Republic of Indonesia Number 6 Of 2018 On Complete Systematic Land Registration (PTSL). This program is intended for middle to low income groups who can have land rights certificates at a low cost, as well as to provide legal certainty guarantees to holders of land rights.

One important thing that must be considered in the implementation of PTSL is the availability of laws and regulations that protect the PTSL process and products. Among them is the issue of the length of time of the announcement as well as the process of checking juridical data that does not go through the adjudication process (land inspection hearing in the field). Complete Systematic Land Registration as a breakthrough in government policy to facilitate the community to obtain land certificates for their land ownership but needs to be reviewed in the form of legal protection for PTSL participants as a form of establishing legal certainty in obtaining legality on land which incidentally is a land that is prone to disputes and conflicts .

Based on the above background, carry out research and study issues regarding land registration in a complete systematic following the problems that occur in the field and the form of legal protection in this case within the scope of Blora Regency as a research area.

Based on the background described above, it can be formulated that the problem in this study is: What is the form of legal protection for participants in a complete systematic land registration program (PTSL) in Blora Regency?

\footnotetext{
${ }^{3}$ Boedi Harsono, 2008, Hukum Agraria Indonesia: Himpunan Peraturan-Peraturan Hukum Tanah, Jakarta: Djambatan, p. 14.

${ }^{4}$ Ibid, p. 18.

${ }^{5}$ Dian Aries Mujiburohman, Otensi Permasalahan Pendaftaran Tanah Sistematik Lengkap (PTSL), Sekolah Tinggi Pertanahan Nasional, Journal Vol 4 No.1, May 2018, p. 89
} 


\section{Research Methods}

To conduct a study in this study the writer uses the sociological juridical method. Juridical is an approach that uses the principles and legal principles derived from written regulations, sociological is an approach that aims to clarify the real situation in the community of the problem under study in other words giving importance to the steps of observation. This method means that in addition to looking at the juridical perspective by looking at the legislation and legal provisions, it also examines the reality in practice in the community.

The specifications in this study are descriptive analysis. The data used for this study are primary and secondary data. To obtain data in this study, data collection methods such as field observations, interviews, and literature study or document study are used. The data that has been obtained is then analyzed by qualitative analysis, namely data analysis by not using numbers, but data obtained through research.

\section{Results and Discussion}

\subsection{Form of Legal Protection for Participants of the Systematic Complete Land Registration Program (PTSL) in Blora Regency}

According to Hans Kelsen, law is normative science and not natural science. ${ }^{6}$ Furthermore, Hans Kelsen explained that law is a social technique to regulate people's behavior. ${ }^{7}$ In language, the word protection in English is called protection. The term protection according to $\mathrm{KBBI}$ can be equated with the term protection, which means that the process or act of protecting, while according to the Black's Law Dictionary, protection is the act of protecting. ${ }^{8}$

According to Hadjon, legal protection for the people includes two things, namely:

- Preventive Legal Protection, which is a form of legal protection where the people are given the opportunity to submit objections or opinions before a government decision gets a definitive form;

- Repressive Legal Protection, which is a form of legal protection which is more intended in dispute resolution. ${ }^{9}$

Conceptually, the legal protection given to the people of Indonesia is the implementation of the principle of recognition and protection of human dignity and sources that are based on Pancasila and the principles of the rule of law based on Pancasila. Legal protection is essentially every person has the right to get protection from the law. Almost all legal relations must receive protection from the law.

Regarding the legal position of the Certificate of Land Rights issued is a legal product of the Regulation of the Minister of Agrarian Spatial Planning / Head of the National Land Agency Number 6 of 2018 On Complete Systematic Land Registration is one of

\footnotetext{
${ }^{6}$ Jimly Asshiddiqie and M. Ali Safa'at, 2006, Teori Hans Kelsen Tentang Hukum, Jakarta: Sekretariat Jenderal dan Kepaniteraan MK RI, p. 12

${ }^{7}$ Hans Kelsen, 2009,Dasar-Dasar Hukum Normatif, Jakarta: Nusamedia, p. 343

${ }^{8}$ Bryan A. Garner, 2009, Black's Law Dictionary, ninth edition, West: St. Paul, p. 1343

${ }^{9}$ Phillipus M. Hadjon, Perlindungan Hukum Bagi Rakyat Indonesia, Surabaya: PT. Bina IImu, 1987, p. 5
} 
the technical implementing rules of land registration which is the mandate of the Basic Agrarian Law Article 19 is to guarantee legal certainty for land rights throughout the territory of Indonesia. Likewise in this case, the position of the certificate of the implementation of a complete systematic land registration as described in the previous discussion is administratively valid and can be accounted for.

One important thing that must be considered in the success of PTSL is the availability of laws and regulations that protect the PTSL process and products. In an interview with a respondent from the Blora Regency Land Office, Suroso Adi Budi, explained that there was a concern that Permen Number 6 of 2018 regarding PTSL could not guarantee legal protection against the certificate issuance process because it was not in accordance with Government Regulation Number 24 of 1997 which was in a hierarchically higher position. Among them was the problem of the length of time of the announcement and the process of checking juridical data that did not go through an adjudication process (a land inspection hearing in the field). ${ }^{10}$

In addition, the basis for the issuance of the Regulation of the Minister of Agrarian Spatial Planning / Head of the National Land Agency Number 6 of 2018 On Systematic Land Registration Complete from the above rules is a more specific technical regulation regarding Complete Systematic Land Registration (Lex Specialist) of Act. No 5 of 1960 On the Principal -R Agrarian Subjects and Government Regulation Number 24 of 1997 On Land Registration. On this basis the Minister of Agrarian Spatial Planning / Head of the National Land Agency uses its authority to accelerate the process of land registration throughout Indonesia. The use of discretion is used to keep abreast of developments in community dynamics that occur that cannot yet be touched by laws and regulations.

The law can be upheld if it considers three elements, namely legal certainty, expediency, and justice. However, of the three elements can not be focused on just one element, because it is not always easy to work for the emergence of a balance between the three elements. Normative legal certainty is a rule that is made and promulgated with certainty because it regulates clearly and logically. ${ }^{11}$ Without legal certainty, a person does not know what will be done and eventually feels uncomfortable, but when too focused on legal certainty, too strict to obey a rule will result in rigid and cause injustice.

Based on this article, the Government has guaranteed legal certainty and legal protection for the community to control land, namely through land registration. PTSL implementation also applies to the principles of land registration that have been listed in Government Regulation Number 24 of 1997 On Land Registration as a legal basis for all land registration programs. ${ }^{12}$ which covers:

- Simple Principle

The principle of simple registration of land is intended so that the basic provisions and procedures can be easily understood by the parties concerned, especially the

\footnotetext{
${ }^{10}$ Interview Results with Suroso Adi Budi, Blora Regency Land Office, on January 23, 2020

${ }^{11}$ Amran Suadi, et al., 2016, Politik Hukum: Perspektif Hukum Perdata dan Pidana Islam Serta Ekonomi Syariah, Jakarta: Kencana, p. 295.

12 Interview Results with Suroso Adi Budi, Blora Regency Land Office, on January 23, 2020
} 
holders of land rights.

- Safe Principle

The principle of safety implies that physical and juridical data research in the procedure of obtaining ownership of land rights be carried out carefully and accurately which is possible using modern computerized technology equipment so that the objective of land registration is achieved, namely legal certainty of ownership of land rights.

- Affordable Principle

The principle of affordable is meant affordability for those who need it, especially by paying attention to the needs and abilities of the economically weak groups. The services provided in the context of organizing land registration must be affordable to those who need it.

- Current Principle

The latest principle means adequate completeness in its implementation and continuity in maintaining its data. Available data must indicate the latest state. For this reason it is necessary to follow the obligation to register and record changes that occur in the future. The latest principle demands the maintenance of land registration data continuously and continuously, so that the data stored in the Land Office is always in accordance with the real situation on the ground and the community can obtain information about the correct data at any time. For this reason, the open principle is applied.

- Open Principle

The principle of openness implies that available land registration data can be informed to the holder or to other parties who need to be used according to applicable procedures. ${ }^{13}$

Implementation carried out by the Blora Regency Land Office in accordance with the Regulation of the Minister of Agrarian Spatial Planning / Head of the National Land Agency Number 6 Of 2018 On Complete Systematic Land Registration in which the completion of PTSL activities consists of 4 (four) clusters, including:

- Cluster 1, i.e. plots of land whose physical and juridical data meet the requirements for the issuance of the Land Rights Certificate;

- Cluster 2, i.e. plots of land whose physical and juridical data meet the requirements for the issuance of their Land Rights Certificate but there are cases in the Court and / or dispute;

- Cluster 3, i.e. plots of land whose physical and juridical data cannot be recorded and issued a Certificate of Land Rights because the subject and / or object of the rights have not fulfilled certain requirements stipulated in this Ministerial Regulation; and

- Cluster 4, i.e. plots of land whose objects and subjects have been registered and have been certified by Land Rights, both uncharted and mapped but not in

${ }^{13}$ Supriadi, 2010, Hukum Agraria, Jakarta; Sinar Grafika, p. 164 
accordance with field conditions or changes in physical data, must be mapped into a Systematic Complete Land Registration Map. ${ }^{14}$

Regarding the settlement if there are data errors both physical data and juridical data at the time the data announcement in the village can be corrected before the certificate is made, but if the certificate has been issued but inside there is a data error, then the wrong data can be submitted to the National Land Agency Office and can be settled through litigation or non-litigation, namely through mediation or by the State Administrative Court. ${ }^{15}$

With the Regulation of the Minister of Agrarian Spatial Planning / Head of the National Land Agency Number 6 of 2018 On Complete Systematic Land Registration, if there are parties who feel their interests are harmed, they can submit an objection to the official who issues the discretionary decision. Regarding the community's objections, the official who issued the discretionary decision must answer it. If the community who feels their interests are harmed is still dissatisfied with the response of the official who issued the discretionary decision, then it can submit an administrative appeal to the direct superior of the official who issues the discretionary decision and the direct superior of the official who issues the discretionary decision must also respond to the administrative appeal.

\section{Closing}

\subsection{Conclusions}

Form of legal protection for PTSL participants in Blora Regency, if there are data errors both physical data and juridical data at the time of the announcement of data in the village it can be corrected before the certificate is made, but if the certificate has been issued but inside there is an error data, then the wrong data objections can be submitted to the Office of the National Land Agency and can be resolved through litigation or non-litigation, namely through mediation or by the State Administrative Court. With the Regulation of the Minister of Agrarian Spatial Planning / Head of the National Land Agency Number 6 of 2018 On Complete Systematic Land Registration, if there are parties who feel their interests are harmed, they can submit an objection to the official who issues the discretionary decision. Against the objections of the community, the official who issues the discretionary decision must answer it. If the community who feels their interests are harmed is still dissatisfied with the response of the official who issued the discretionary decision, then it can submit an administrative appeal to the direct superior of the official who issues the discretionary decision and the direct superior of the official who issues the discretionary decision must also respond to the administrative appeal. For PTSL objects that are already known but a dispute has occurred during the PTSL process, the certificate issuance will be postponed and the dispute resolved in accordance with the land cluster. If the community who feels their interests are harmed is still dissatisfied with the response of the official who issued the discretionary decision,

\footnotetext{
${ }^{14}$ Regulation of the Minister of Agrarian Spatial Planning / Head of National Land Agency Number 6 of 2018 concerning Complete Systematic Land Registration

${ }^{15}$ Interview Results with Suroso Adi Budi, Blora Regency Land Office, on January 23, 2020
} 
then it can submit an administrative appeal to the direct superior of the official who issues the discretionary decision and the direct superior of the official who issues the discretionary decision must also respond to the administrative appeal. For PTSL objects that are already known but a dispute has occurred during the PTSL process, the certificate issuance will be postponed and the dispute resolved in accordance with the land cluster. If the community who feels their interests are harmed is still dissatisfied with the response of the official who issued the discretionary decision, then it can submit an administrative appeal to the direct superior of the official who issues the discretionary decision and the direct superior of the official who issues the discretionary decision must also respond to the administrative appeal. For PTSL objects that are already known but a dispute has occurred during the PTSL process, the certificate issuance will be postponed and the dispute resolved in accordance with the land cluster.

\subsection{Suggestions}

- The Blora Regency Land Office should pay more attention to the implementation of PTSL, which is related to the elimination of the applicant from PTSL participants verbally, either through the village committee or the direct applicant. This needs to be considered further because it relates to a person's right to obtain legal certainty over his land;

- The Blora Regency Land Office must increase cooperation with local governments in the implementation of PTSL activities, in order to optimize the activities rather than the implementation. Then this must start with more forms of coordination between the Blora Regency Land Office, the Regional Government and the community.

\section{References}

\section{Book}

[1] Amran Suadi, et al., 2016, Politik Hukum: Perspektif Hukum Perdata dan Pidana Islam Serta Ekonomi Syariah, Jakarta: Kencana

[2] Boedi Harsono, 2008, Hukum Agraria Indonesia: Himpunan Peraturan-Peraturan Hukum Tanah, Jakarta: Djambatan

[3] Bryan A. Garner, 2009, Black's Law Dictionary, ninth edition,West: St. paul

[4] Hans Kelsen, Dasar-Dasar Hukum Normatif, (Jakarta: Nusamedia, 2009)

[5] Jimly Asshiddiqie and M. Ali Safa'at, 2006, Teori Hans Kelsen Tentang Hukum, Jakarta: Secretariat General and Registrar of the Constitutional Court of the Republic of Indonesia

[6] Phillipus M. Hadjon, 1987, Perlindungan Hukum Bagi Rakyat Indonesia, Surabaya: PT. Bina Ilmu

[7] Supriadi, 2010, Hukum Agraria, Jakarta: Sinar Grafika

\section{Statutory Regulations}

[1] The 1945 Constitution of the Republic of Indonesia 
[2] Law of the Republic of Indonesia Number 5 of 1960 On Basic Regulations on Agrarian Principles

[3] Government Regulation Number 24 of 1997 On Land Registration

[4] Regulation of the Minister of Agrarian Affairs and Spatial Planning / Head of the National Land Agency of the Republic of Indonesia Number 6 of 2018 On Complete Systematic Land Registration

\section{Journal}

[1] Dian Aries Mujiburohman, Otensi Permasalahan Pendaftaran Tanah Sistematik Lengkap (PTSL), Sekolah Tinggi Pertanahan Nasional, Journal Vol 4 No.1, May 2018 